Check for updates

The BMJ

fgodlee@bmi.com Follow Fiona on Twitter @fgodlee

Cite this as: $B M J 2021 ; 375: 12441$ http://dx.doi.org/10.1136/bmj.n2441 Published: 07 October 2021

\title{
A world on the edge of climate disaster
}

\section{Fiona Godlee editor in chief}

The world is heating up and so is the urgency for action. Without radical change in the way we live, move, eat, work, and play, rising global temperatures will result in irreversible planetary change, with catastrophic consequences for humanity. These are strong words but they are backed by science. The International Panel on Climate Change says that, to keep the post-industrial global temperature rise below the tipping point of $1.5^{\circ} \mathrm{C}$, the world must halve its emissions of carbon dioxide and other greenhouse gases by 2030 and reach net zero by 2050 . At current rates of emissions we in the UK will use up our individual carbon budgets in less than four years (doi:10.1136/bmj.n2391).

But who is it that must change? Must we wait for our governments to enact the necessary radical reforms? In which case, despite the rhetoric and the impending gathering of world leaders in Glasgow next month, we will almost certainly be disappointed (https://blogs.bmj.com/bmj/2021/10/o7/cop26-amissed-opportunity-for-climate-leadership), ${ }^{2}$ and this precious chance to avert human and natural disaster will be lost (doi:10.1136/bmj.n2329). ${ }^{3}$

Government action is essential, as this week's special issue of The BMJ on the climate emergency makes clear. But our editorial also calls on us all to act as individuals in our different spheres of influence (doi:10.1136/bmj.n2425) ${ }^{4}$ : as family members, citizens, and respected members of our communities; as diagnosticians, prescribers, and managers of healthcare resources(doi:10.1136/bmj.n2407) ${ }^{5}$; as educators, trainers, and curriculum leaders (doi:10.1136/bmj.n2385) ${ }^{6}$; as designers of healthcare systems (doi:10.1136/bmj.n2408)7 ; as public health professionals with an understanding of the wider determinants of health; and as members of any organisation, since membership allows, indeed requires, us to hold those in authority to account. The responsibility to act is especially strong on us as health professionals, given our remit to promote and protect health and our trusted and privileged position in society.

Hope is essential, to ward off eco-anxiety (https://blogs.bmj.com/bmj/2021/10/06/the-climatecrisis-and-the-rise-of-eco-anxiety) ${ }^{8}$ and to spur ourselves and others on to effective action. Healthcare can bring down its carbon footprint, and in the UK is doing so (doi:10.1136/bmj.n2337). ${ }^{9}$ Structural changes to our physical and economic environments have the potential to drive behaviour change and substantially cut emissions (doi:10.1136/bmj.n2293). ${ }^{10}$ And the right economic decisions could lead us into a sustainable, inclusive, and resilient global future (doi:10.1136/bmj.n2405). ${ }^{11}$

Collectively and individually we must lead by example: driving system change in healthcare to reduce emissions and waste, advocating for national and international political action, and educating our patients and the public

(https://blogs.bmj.com/bmj/2021/10/07/talking-topatients-about-the-climate-emergency) $)^{12}$ to help safeguard the future of our planet and its people. We can't wait for someone else to act. We don't have time for that.

\section{See more of The BMPs articles on the climate emergency at https://www.bmj.com/campaign/climate-emergency.}

Campbell IRU. UK's share of the global carbon budget will be used up in 3.3 years. BM/2021;374:n2391. doi: 10.1136/bmi.n2391 pmid: 34593544

2 Wardrope A. COP26: a missed opportunity for climate leadership. BMJ Opinion. Oct 2021. https://blogs.bmi.com/bmi/2021/10/07/cop26-a-missedopportunity-for-climate-leadership.

3 Murage P, Batalha HR, Lino S, Sterniczuk K. From drug discovery to coronaviruses: why restoring natural habitats is good for human health. BMJ 2021;375:n2329doi: 10.1136/bmj.n2329.

4 Dobson J, Cook S, Frumkin H, Haines A, Abbasi K. Accelerating climate action: the role of health professionals. BM/2021;375:n2425.

5 Barratt A, McGain F. Overdiagnosis is increasing the carbon footprint of healthcare. BM/2021;375:n2407. doi: 10.1136/bmi.n2407 pmid: 34607810

6 Moore A. A planetary health curriculum for medicine. BM/2021;375:n2385.

7 Oliver D. David Oliver: Outpatient clinics' role in sustainability. BMJ 2021;375:n2408doi: 10.1136/bmj.n2408.

8 Rao M, Powell RA. The climate crisis and the rise of eco-anxiety. BMJ Opinion. Oct 2021. https://blogs.bmj.com/bmi/2021/10/06/the-climatecrisis-and-the-rise-of-eco-anxiety.

9 Wilkinson E. How to achieve a net zero carbon NHS during a pandemic. BMJ 2021;375:n2337

10 Marteau T, Chater N, Garnett EE. Changing behaviour for net zero 2050 2021;375:n2293

11 Stern N, Patel IG, Ward B. Covid-19, climate change, and the environment: a sustainable, inclusive, and resilient global recovery. BMJ2021;375:n2405.

12 Harvey G, Tomson M, Cussans A, et al. Talking to patients about the climate emergency. BMJ Opinion. Oct 2021. https://blogs.bmj.com/bmi/2021/10/07/talking-to-patients-about-the-climate-emergency. 